\title{
A View of Indonesian Anti-Corruption Class for Academic Students
}

\author{
Parji \\ PGRI Madiun University: Civic Teaching Dept \\ East Java, Indonesia
}

\author{
Fida Chasanatun \\ PGRI Madiun University: Primary Teaching Dept \\ East Java, Indonesia \\ Fidach71unipma@gmail.com
}

\begin{abstract}
This article purposes in examining the application of anti-corruption education model through hero biography recession, its effectiveness as the instructional effect and the nurturing effect. The research conducted in PGRI Madiun University, especially Counseling Teaching Department. It has 31 students as the sample of experiment class, and 35 students as the control class. The data resources measured quantitatively and qualitatively. The comparison between students score from both classes are processed by independent sample test. The data of student interview is classified into six groups. The conclusion of this study are: (1) The Anti-corruption Education Model through Hero Biography Recession is effective as the score of the experiment class is better than the score of the control one; (2) the example and role of models in anti-corruption education are from as many as people in the society, including teachers, principals, the National Heroes, and also the individual himself; (3) there is relationship among the ability of reading, the motivation in finding information, and the affective mastery in learning.
\end{abstract}

Keywords-the Anti-corruption Education Model; Biography Recension

\section{INTRODUCTION}

Education is organized by giving role models, building will and developing creativity. So to realize anti-corruption education, it must be a joint responsibility between the family, community and government, because that education lasts for life and is carried out within the family, school, and community. Education here consists of three parts, namely informal education (family), formal (school) and non-formal (community), which can complement and enrich each other. Therefore, the target to be achieved from education is the formation of cognitive, affective and psychomotor aspects (skills). So ideally, the formation of cognitive aspects becomes the duties and responsibilities of educators in schools, the formation of effective aspects becomes the tasks and responsibilities of parents, by building personalities and habits. Meanwhile, the formation of psychomotor aspects is the duty and responsibility of the community. With the division of tasks like this, the problem of anti-corruption education is actually the responsibility of all parties: parents, educators (teachers), and the community [1]

The implementation of anti-corruption education is given in the form of a book containing lecturer guidelines to teach the material contained in the Anti-Corruption Education Book for
Higher Education. These components include: (1) Definition of Corruption, (2) Corruption Factors, (3) Massive Impact of Corruption, (4) Anti-Corruption Values and Principles, (5) Corruption Eradication Efforts, (6) International Movement, Cooperation and Prevention Instruments Corruption, (7) Corruption in the Statutory Regulations, and (8) The Role of Students in the Anti-Corruption Movement. This book is also equipped with a Learning Model for Anti-Corruption Education Subjects. The final section includes an Appendix which consists of a guide on making Posters and a guide on Investigating Behavior Corruption [2].

\section{A. Anti Corruption Lesson for Academic Class: the syntax}

\section{1) Social System}

Routine activities related to the success of the program require preparation in the form, syllabus and lesson plan, biography books, figures, classes and all equipment (LCD, board, etc). the meeting was designed in three types of activities; question and answer evaluation; and guest lecture. In the discussion activities, each group of students presented the material that they had learned through books and internet sites. In the guest lecture, students get the opportunity to learn to write reviews from language experts and discuss the difficulties in writing.

\section{2) Learning Syntax}

Learning has several steps. The steps are arranged in order: Preparation; Reading together; Dialogue or Discussion; Individual Holding Power; Self Control. Rationalism Narratives, Emotion as Guilt; Likelihood Acting Corruption; Evaluation. In the preparation step students are asked to understand the parts of the student worksheet that must be filled in accordance with learning objectives. The groups that have been divided determine the names of the figures and the reasons why they choose them as anti-corruption fighters. Group discussions are held to find data and news on the internet about the character. After the data has been declared sufficient, each group presents preliminary data based on the next five steps of the discussion. After all groups have finished presenting their characters, an evaluation of the strengths and weaknesses of the review is carried out. Learning at the next class meeting is carried out discussion on filling student worksheets adjusted to the discussion of the warrior biography book. Several meetings were held until the students stated that 
they had made perfect character reviews in accordance with the specified targets.

\section{3) Principal Of Reaction}

Learning in a class or activity can not be separated from a rule for all elements that implement it. Included in the elements of these rules is the Principal of Reaction or how to view, treat or respond to questions and student conditions as a result of the learning process. For the success of the process Jalongo [3] provides direction for the emergence of sense of community in meaningful scratching activities from early literacy so that teachers behave or respond with reference: (1) Pay attention in responding to the suitability of the response with the attitudes and values believed by students; (2) Using straightforward language and does not contain biased or ambiguous meanings; (3) Noting the possibility of different meanings arising from the language used differently; (4) Using various possibilities of delivery to students; (5) Providing opportunities for activities for students who have an initiative and desire themselves; (6) Provide as many opportunities as possible for the various opinions and differences of each student in the class.

\section{4) Support System}

An explanation of the content of the material and the types of activities related to language games is a Support System that has an Anti-Corruption learning model. Provision of teaching materials in the form of anti-corruption figures biography books, student worksheets, and summary notes of discussions with experts and class members enable students to analyze the lives of the figures he admires as role models and role models through systematic writing that contains three things: (1) book source evaluating; (2) biography resume; (3) five components of anti-corruption fighted value (Individual Holding Power; Self Control, Rationalism Narratives, Emotion as Guilt, Likelihood Acting Corruption). The clear teaching learning steps are shown in table 1.

\section{METHODS}

This study applies a mixed research method by using a sample of two classes formed randomly from five classes owned. Members of the two classes were randomly selected from 175 students of the Guidance and Counseling Study Program at PGRI Madiun University, who received AntiCorruption courses in the third semester of the 2018-2019 academic year. 35 students were selected in one class as a control class while the other class as many as 31 students as an experimental class. The final data processing value is compared using an independent sample test. The difference in the number of students in the two classes was due to the absence of students at the first three meetings which resulted in students not being allowed to attend the next program. Based on student grade data, interviews were conducted from six student groups involved in classroom learning.
TABLE I. SYNTAX OF ANTI-CORRUPTION LEARNING MODEL WITH HERO BIOGRAPHY RECESSION

\begin{tabular}{|c|c|c|}
\hline \multicolumn{3}{|c|}{ TL Steps in Class } \\
\hline Syntax & objectives & SS act \\
\hline Lead-in & $\begin{array}{l}\text { Provide } \\
\text { motivation and } \\
\text { foster curiosity }\end{array}$ & $\begin{array}{c}\text { Determine } \\
\text { information, } \\
\text { according to the } \\
\text { worksheet }\end{array}$ \\
\hline $\begin{array}{l}\text { Reading as } \\
\text { finding } \\
\text { information }\end{array}$ & $\begin{array}{l}\text { Anti-Corruption } \\
\text { fighter as a model }\end{array}$ & $\begin{array}{l}\text { Determine the } \\
\text { name of the hero } \\
\text { and the reason } \\
\text { for the selection }\end{array}$ \\
\hline $\begin{array}{l}\text { Dialogue and } \\
\text { discussion }\end{array}$ & $\begin{array}{l}\text { Information } \\
\text { sharing }\end{array}$ & $\begin{array}{c}\text { Students ask, } \\
\text { showing interest } \\
\text { in finding more } \\
\text { information }\end{array}$ \\
\hline $\begin{array}{c}\text { Individual } \\
\text { Holding Power }\end{array}$ & $\begin{array}{l}\text { Provide } \\
\text { reinforcement to } \\
\text { the meaning and } \\
\text { form of character } \\
\text { activities as } \\
\text { evidence of the } \\
\text { power possessed }\end{array}$ & $\begin{array}{l}\text { Find information } \\
\text { according to } \\
\text { direction }\end{array}$ \\
\hline $\begin{array}{c}\text { Self-Control. } \\
\text { Rationalism } \\
\text { Narratives, } \\
\text { Emotion as Guilt }\end{array}$ & $\begin{array}{l}\text { Doing a track } \\
\text { record of mental } \\
\text { development and } \\
\text { turmoil problems } \\
\text { faced by the } \\
\text { character }\end{array}$ & $\begin{array}{l}\text { Find information } \\
\text { according to } \\
\text { direction }\end{array}$ \\
\hline $\begin{array}{l}\text { Likelihood } \\
\text { Acting } \\
\text { Corruption }\end{array}$ & $\begin{array}{l}\text { Identifying the } \\
\text { character's attitude } \\
\text { towards the } \\
\text { corruption } \\
\text { environment }\end{array}$ & $\begin{array}{l}\text { Find information } \\
\text { according to } \\
\text { direction }\end{array}$ \\
\hline Evaluation & Evaluation & Evaluation \\
\hline
\end{tabular}

\section{RESULTS AND DISCUSSION}

The data of students' final score is presented into two group. Those are control and experiment class. Both classes have a normal distribution data. Normality Test is a test conducted with the aim to assess the distribution of data in a group of data or variables, whether the distribution of data is normally distributed or not. The test was carried out using the Kolmogorov Smirnov formula. The composition of scores are as follows:

TABLE II. CONTROL CLASS SCORE

\begin{tabular}{|l|c|c|c|c|c|c|}
\hline & Statistic & Df & Sig. & Statistic & Df & Sig. \\
\hline CONTROL & .119 & 35 & .200 & .946 & 35 & .086 \\
\hline
\end{tabular}

Score Sig $=0.200>0.05$

From the result of the normality test, it can be concluded that the data is normal distributed. The data of experiment class us as follows: 
TABLE III. EXPERIMENT CLASS SCORE

\begin{tabular}{|l|c|c|c|c|c|c|}
\hline & Statistic & Df & Sig. & Statistic & Df & Sig. \\
\hline EXPERIMENT & .142 & 31 & .112 & .937 & 31 & .069 \\
\hline
\end{tabular}

Score Sig $=0.112>0.05$

From the result of the normality test, it can be concluded that the data is normal distributed

The comparison of two class score shows that students in experiment class have gained more mastery learning than in control class. The comparison is as follows:

TABLE IV. THE TWO CLASS SCORE COMPARISON

\begin{tabular}{|l|c|c|c|c|c|}
\hline & Grup & $\mathbf{N}$ & Mean & $\begin{array}{c}\text { Std. } \\
\text { Deviation }\end{array}$ & $\begin{array}{c}\text { Std. } \\
\text { Error } \\
\text { Mean }\end{array}$ \\
\hline CONTROL & 1.00 & 35 & 2.4143 & .87855 & .14850 \\
\hline EXPERIMENT & 2.00 & 31 & 2.8226 & .74776 & .13430 \\
\hline
\end{tabular}

The average score of the control class (2.4143) is smaller than the average score of the experimental class (2.8226) so it can be concluded that the learning mastery of the experimental class is better. Than the other class.

The last step of the research is interviewing the students. The students of the experiment class are divided into score groups. The composition are as follows:

TABLE V. EXPERIMENT CLASS SCORE GROUP

\begin{tabular}{|c|c|c|}
\hline Group & Score & Number of students \\
\hline A & 1.5 & 3 \\
\hline B & 2 & 4 \\
\hline C & 2.5 & 7 \\
\hline D & 3 & 7 \\
\hline E & 3.5 & 3 \\
\hline F & 4 & 4 \\
\hline
\end{tabular}

Those students are grouped in order to be interviewed about their learning activity in the class. The questions in the interview are about the activities in completing the information of anti-corruption fighters, as: reading book, Individual Holding Power; Self Control, Rationalism Narratives, Emotion as Guilt, and Likelihood Acting Corruption. They are asked to choose five options; too easy, easy, too bad, difficult, and too difficult. The answers are as follows:
TABLE VI. STUDENTS INTERVIEW ANSWER

\begin{tabular}{|c|c|c|c|c|}
\hline Group & $\begin{array}{c}\text { Book } \\
\text { reading }\end{array}$ & $\begin{array}{c}\text { Individual } \\
\text { Holding } \\
\text { Power }\end{array}$ & $\begin{array}{c}\text { Self } \\
\text { Control. } \\
\text { Rasionalism } \\
\text { Narratives, } \\
\text { Emotion as } \\
\text { Guilt }\end{array}$ & $\begin{array}{c}\text { Likelihood } \\
\text { Acting } \\
\text { Corruption }\end{array}$ \\
\hline A & difficult & Ok & Ok & difficult \\
\hline B & difficult & Ok & difficult & difficult \\
\hline C & Ok & Easy & difficult & Easy \\
\hline D & Easy & Easy & difficult & Easy \\
\hline E & Easy & Easy & Easy & Easy \\
\hline F & Easy & Easy & Easy & Easy \\
\hline
\end{tabular}

This above data shows that the students in group A and B think that reading is not an easy activity. As those thinking the activities related to reading are considered difficult too. Group A cannot find the information about the environment the hero living. Group B think that the only ok activity for them doing is finding the hero power and well living that might make him doing corruption. Group $\mathrm{C}$ think that the difficult activity is finding information related to hero's emotion. This condition is experienced also by group $\mathrm{D}$. the students who think reading is easy find easy to gaining the learning objectives.

\section{CONCLUSION}

From the above explanation, it can be conclude several matters, as : (1) The Anti-corruption Education Model through Hero Biography Recession is effective as the score of the experiment class is better than the score of the control one; (2) the example and role of models in anti-corruption education are from as many as people in the society, including teachers, principals, the National Heroes, and also the individual himself; (3) there is relationship among the ability of reading, the motivation in finding information, and the affective mastery in learning.

\section{REFERENCES}

[1] Sulistyawati, Sri, Wisnawaty, \& Purba, Nelvitia, "Anti corruption education through character building value", IOSR-JHSS. 22. Issue 1. 711, 2017.

[2] Komalasari, Kokom, \& Saripudin, Didin, "Integration of anti-corruption education in school activities", American Journal of Applied Sciences. 122(6). 445-451, 2015.

[3] Jalongo, M.R. Early Childhood Language Arts. USA: Pearson Press, 2007. 